\title{
The Use of Think Talk Write Strategy in Improving Students' Writing Spoof Ability on English Department FKIP USI Pematangsiantar
}

\author{
Anita Purba', Semaria Eva Elita Girsang ${ }^{2}$ \\ ${ }^{1,2}$ Faculty of Educational Sciences, Universitas Simalungun, Indonesia \\ anit_apurba@yahoo.co.id
}

\begin{abstract}
The aims of the research were: (1) To know that Think-Talk-Write Strategy can improve the students' writing Spoof ability and (2) To describe the process of Think-Talk-Write-Strategy in improving students' writing Spoof ability. This research was conducted at English Department FKIP USI at the fifth Semester in the Academic Year of 2018/2019. The population were 21 students. The qauntitative data were taken from the scores of the pre-test and post-test. The total score is 1111, the mean 52, 9 thus, in the post test found the total score is 1701, the mean 81.Think-TalkWrite Strategy inspired both the students and the researcher in improving the ability of English especially on writing. The students could practice their skill of English in the different situation and treatment. They could express their idea or opinion freely as the researcher only became mediator during the activities of ThinkTalk-Write Strategy as it was student-centred. In fact, the students' cooperation increased. They helped each other, communicated using English, and built the idea, imagination and opinion that they wanted to compose in their writing during applying ThinkTalk-Write Strategy.
\end{abstract}

\section{Keywords}

writing, spoof text; think talk, wite strategy

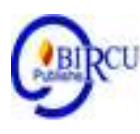

\section{Introduction}

Nowadays, English is one of the international languages which have become popular. People use it to have international communication and to cooperate among people in different countries. Because of this reason, Indonesian government decided English to be taught at schools as the first foreign language. There are four language skills in teaching English, they are listening, speaking, reading, and writing.

Generally, language can be spoken and written, so it is also important and necessary to learn writing. Writing is different from other language skills. In listening and reading,the students communicate using their own ideas and feeling that sometimes involves on interlocutor, so there are collocations among them in conversation. On the other hand,communication through the written form needs real proficiency from the writer in order to be effective. Writing is an activity that produces something become sentences meaningful. Make a good writing started from arrange the sentence according the sequence. Shortly, writing skills are specific abilities which help writer put their thoughts into words in a meaningful form and mentally English Subject, especially when they were writing a simple text . In this case, this is not only about the weakness of students or not about their mistakes. But, teachers also have the important position as educator to motivated them to writing a simple text. One of the good way of teacher to make the students enjoy or writing a sentence 
or simple text is with looking for or finding about the good method or technique for improving their writing ability.

English language materials can be evaluated as they stand, without their roles in the classroom. However, this sort of evaluation does not help very much as it gives us no piece of information as to how the material works in the classroom (Breen in Ali, 2019). His ideas pave the ground for an evaluation of different aspects of the materials in process to get information about the ways in which students and teachers react to them.

According to Dalman (2014: 3) states "Writing is an activity communication in the form of delivering messages (information) in writing to other parties with use written language as a tool or medium. Writing activities involve several elements, namely: the writer as a messenger, the contents of the writing, the channel or the media, and reader.

Harmer in Putri et al 2015 stated that writing is frequently useful as preparation for some other activity, in particular when students write sentence as preamble to discussion activities. There are some rules of the teacher when students are asked to write the one that are especially important are as follows:

a. Motivator: writing tasks will be motivate the students, creating the right conditions for the generation of ideas, persuading them of the usefulness of the activity, and encouraging them to make as much effort as possible for maximum benefit.

b. Recource: especially during more extended writing task, we should be ready to supply information and language where necessary. We need to tell students that we are available and be prepared to look at their work as it progresses, offering advice and suggestion in a constructive way. Becouse writing takes longer than conversation, for example, there is usually time for discussion with individual student or students working in pairs or groups to complete a writing tasks.

c. Feedback provider: teachers should respond positively and ancouragingly to the content of what the students have written. When offering correction, teachers will choose what and how much to focus on, based on what students need at this particular stage of their studies and on the tasks they have undertaken.

In writing students try to elaborate their idea or they must express idea to achieve writing form. Moreover, writing can also develop the writers' understanding of an issue by organizing their ideas on a peace of paper. Writing is very interesting to be learned, because many learners considered that writing as the most difficult as other skills.

Through writing, people can explain or describe many things. As a result, people miles away from the writer can get information by reading the written message. Many problems that students faced about. Many kinds of text that will be write by students, for example Spoof text. Spoof is a text which tells factual story, happened in the past time with unpredictable and funny ending. Its social function is to entertain and share the story. Spoof is a type of story which have has twist (funny part in the end of the story). It contains an unpredictable event which makes the story funny. In teaching writing, the teacher has different kinds of method and strategy.

Genre is a term for grouping text together, representing how writers typically use language respond to recurring sttuations. According to Hartono in Yessi Anggreini at all, genre is used to refer to particular text-types, not to traditional varieties of literature. It is type or kind of text, defined in social purposes; also the level of context dealing with social purpose.

Spoof is a type of story which have has twist (funny part in the end of the story). It contains an unpredictable event which makes the story funny". So it usually contains funny story, funny word games or it could be a combination of both. 
The generic structure of spoof text:

1. Orientation (introduction of the participant of the story, where it happen and when. By giving the orientation, reader will recognize the story)

2. Events (tells about the chronological of the story. Several events are explored in chronological way which able to arrange the story read nicely.)

3. Twist (an unpredictable plot in the end of the story which amuses the reader. Readers even did not predict before that it would be)

Think Talk Write (TTW) was firstly introduced by Huinker and Laughlin in 1996. As

Yamin and Ansari in Putri Giska said this technique is developed based on the fact that learning is a social behavior process. In this technique, students are encouraged to think, to talk, and to write based on certain topic. This technique aims to train and to enhance the students' ability to think and to write.

TTW is classified as cooperative learning which means that students are put into group in which they are working together to reach the learning objectives. As Killen in ELT-Tech Journal by Rozi Setiawan, et all 2017 page 3 states cooperative learning is both an instructional technique and a teaching philosophy which aims to encourage students to work together to gain their maximum learning, either their own learning, or the peers learning. Some teachers consider that the use of cooperative learning is effective in group which consists of four students which aims to accomplish certain material.

Yamin and Ansari in Putri Giska state that think talk- write is built of activities such as thinking, talking, and writing. This technique also builds for thought and reflection, also for organizing ideas and testing these ideas before students are ready to write. The flow of TTW technique starts from students enganging in thought or doing reflective dialog with themselves, talking and sharing ideas with the others, and finally writing

Based on the explanation above the researcher is inspired to conduct a research entitled "The Use of Think Talk Write Strategy in Teaching Writing Spoof Text On English Department Students FKIP USI Pematangsiantar".

\section{Research Method}

The population of this research were the fifth semester students of English Department FKIP USI academic yaear 2018/2019 and the sample were 21 students.

The methodology perform to get the data was as follow:

1. Pre test

Where, researcher found the product writing Spoof text from collected, and scoring without giving treatment.

2. Post test

Where, reseracher taught students about Spoof text with using TTW Strategy, as the steps below:

First, researcher ask the students to think and give some interesting title or topic. Second, the researcher make some little groups in class, to discuss about their topic. Third, after discuss the researcher asked every groups to write down a Spoof text based on their tittle and what they are talking about it. The last researcher collected their product writing and giving the score with using formula below: 


\begin{tabular}{|l|l|c|}
\hline Part & \multicolumn{1}{|c|}{ Category } & Score \\
\hline \multirow{4}{*}{ Content } & Excellent to very good & $30-27$ \\
\cline { 2 - 3 } & Good to average & $26-27$ \\
\cline { 2 - 3 } & Fair to Poor & $21-17$ \\
\cline { 2 - 3 } Organization & Very poor & $16-13$ \\
\hline \multirow{4}{*}{ Vocabulary } & Excellent to very good & $20-18$ \\
\cline { 2 - 3 } & Good to average & $17-14$ \\
\cline { 2 - 3 } & Fair to Poor & $13-10$ \\
\cline { 2 - 3 } & Very poor & $9-7$ \\
\hline \multirow{4}{*}{ Grammar } & Excellent to very good & $20-18$ \\
\cline { 2 - 3 } & Good to average & $17-14$ \\
\cline { 2 - 3 } & Fair to Poor & $13-10$ \\
\cline { 2 - 3 } & Very poor & $9-7$ \\
\hline & Excellent to very good & $25-22$ \\
\cline { 2 - 3 } & Good to average & $21-18$ \\
\cline { 2 - 3 } & Fair to Poor & $17-11$ \\
\cline { 2 - 3 } & Very poor & $10-5$ \\
\hline \multirow{5}{*}{ Mechanics } & Excellent to very good & 5 \\
\cline { 2 - 3 } & Good to average & 4 \\
\cline { 2 - 3 } & Fair to Poor & 2 \\
\cline { 2 - 3 } & Very poor & 3 \\
\hline
\end{tabular}

The formula for founding the Mean and Standart Deviation is

Mean $=\frac{\Sigma \mathrm{X}}{\mathrm{N}}$
$\mathrm{SD}=\sqrt{\left(\mathrm{Xi-} \mathbf{X}^{-} \mathrm{X}\right)^{2}}$

$$
\text { (n - 1) }
$$

\section{Result and Discussion}

\subsection{Result}

After giving pre test and got the total score that is 1111 , the mean 52, 9 and in the post test got the total score is 1701 , and the mean 81 . From the data was calculated the standart deviation for pre test is 236 and for post test is 363 . From the result above, it can conclude that using of TTW Strategy can improve the students writing ability especially in writing spoof text.

\subsection{Discussion}

TTW Strategy inspired both the students and teachers in improving the ability of English especially on writing Spoof text. The students could practice their skill of English in the different situation and treatment. They could express their idea or opinion freely as the researcher only became mediator during the activities of TTW Strategy as it was studentcentred. In fact, the students' cooperation increased. They helped each other, communicated using English, and built the idea, imagination and opinion that they wanted to compose in 
their writing during applying TTW Strategy. The students changed their perception that writing was difficult. They thought that writing was fun and interesting.

The students also experienced the situation in which they wrote based on 3 steps in which two of the steps being practiced in group or team. They could change their mindset that writing was not always started individually but in group or team in the process of building the idea, imagination and opinion before expressing them in individual composition. They also learned English on writing lecture not only from the teacher but also from their friends. Furthermore, TTW Strategy inspired the researcher about a good strategy in teaching writing as they could be classified as an effective strategy. This strategy had clear and easy procedure to use and practice. It could make the students change the perception that writing was not difficult lecture and it was easy to practice. It made the students understand the material fast and practiced it in a relax situation of the class. Based on the findings, it could be concluded that in general TTW Strategy could improve the writing skill of the students of the fifth semester of English Department students at University of Simalungun.

\section{Conclusion}

The conclusion of this research is that TTW is a strategy to make students creative in building their ideas and students should do thinkings, an discussing before writing. Through the data analysis and from the findings gained from the students score on writing spoof text in pre test and post test, it was conclude that the contribution of TTW in writing Spoof improves student's ability. The findings revealed that after using TTW strategy, the student's score were significantly better in post test rather than pre test. The total score in pre test is 1111 , the mean 52, 9 and the standart deviation is 236. While in the post test found the total score is 1701, the mean 81 and Standart deviation is 363. It can be stated that TTW Strategy is effective to use in teaching writing Spoof text of English Department students FKIP USI Pematangsiantar.

\section{References}

Ali, W. T. (2019). Cooperative Learning (CL) in Promoting Oral Group Lessons. Budapest International Research and Critics Institute-Journal (BIRCI-Journal). P. 299-306

Aziz, Muhyiddin and Eda Maaliah. (2017). The Application of Thnik Talk Write Strategy Improve the Students Writing Skill : A Classroom Action Research on INOVISH Journal, vol.2 No.2.

Harmer,Jeremy. (2007). How to Teach Writing. London: Stention Associates.

Hartono, Rudi. (2005). Genre of Texts, Semarang:UNNES

Mulyasa, 2009. Praktik Penelitian Tindakan Kelas. Bandung: PT.Remaja Rosdakary

Putri,Giska and Ratna Prasasti. (2015). The effectiveness of Think Talk Write Startegy in Teaching Writing descriptive text on Perspektive English Language and Learning Journal Vol.2 No.2.

Suzanna, Made, at al. (2017). The effect of Think Talk Write Technique on Students Writing $\begin{array}{lllll}\text { Ability on } & \text { ELT-Tech } & \text { journal } & \text { vol.1 }\end{array}$ Www:http//Thinktalkwriteforwritingdescriptive.isi.thesis.Google searched on May 2nd 2018 at $01.30 \mathrm{pm}$

Yessy Anggraini at all, Improving Students' Writing Skill Of Narrative Text Through Video At Grade XII IPA 2 Of SMA N 2 Bukittinggi, Journal English Language Teaching (ELT) Volume 2 Nomor 2, Juli 2014. 